Original Research

\title{
Correlation between Nutritional Status (According to Body Weight/Body Height Index) with the Age of Menarche on Female Student
}

\author{
${\text { Dwi Prasetyaningati }{ }^{*} \text { \& Agustina Maunaturohmah }}^{1}$ \\ ${ }^{1}$ STIKES Insan Cendekia Medika Jombang, Jombang, Indonesia
}

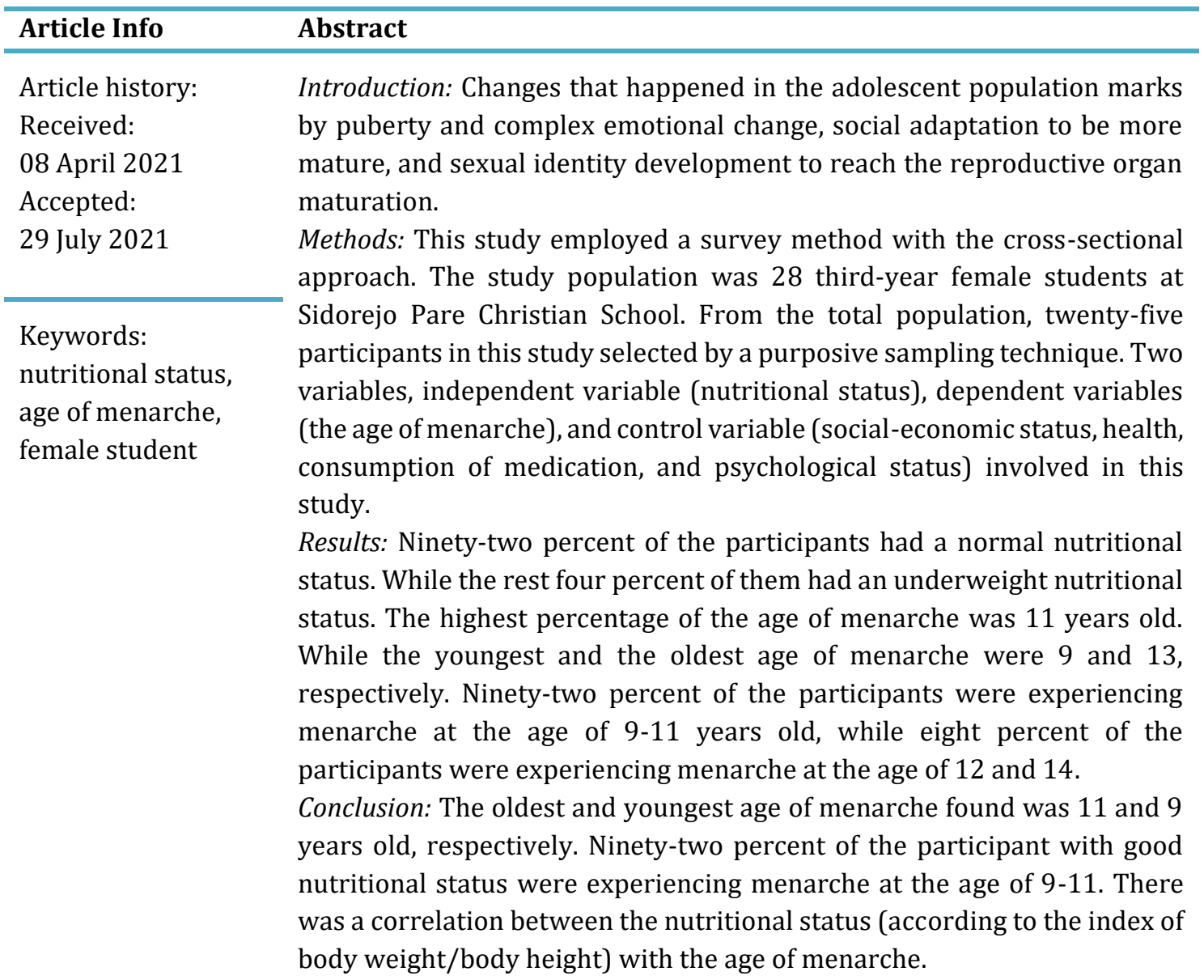

*Corresponding Author:

e-mail: dwiprasetya_82@yahoo.com

This work is licensed under a Creative Commons Attribution 4.0 International License. 


\section{INTRODUCTION}

Changes that happened in the adolescent population marks by puberty and complex emotional change, social adaptation to be more mature, and development of sexual identity to reach the reproductive organ maturation. Adolescent population is vulnerable to nutritional issue due to fast body growth and development, lifestyle change, and habit to experiment with food tasting [1].

Adolescence is a transition period between childhood and young adulthood. It happens at the age of 10 to 19 years old. Girls will start their menstruation marks by the period of menarche. The period of menarche occurs in the age $>12$ years old or below the age of 12 (early menarche) [2]. The age of menarche is actually varied. Today, the age of menarche tends to happen at a younger age. Menarche happens in the age range of 8 to 16 years old. The age of menarche is directly affected by race, audio-visual stimulation, junk food/fast food consumption, socialeconomic status, and BMI [3].

Nutritional status influences the age of menarche in the female adolescent population. Poor nutritional status linked with older age of menarche, while good nutritional status correlated with the younger age of menarche.

Puberty is associated with the acceleration of physical growth, development, and maturation of the adolescent body. Menarche signals the puberty period in a female adolescent. The occurrence of menarche supported by their nutritional status. Good nutritional and health status linked with younger age of menarche. A study conducted in Yogyakarta that involved 562 adolescents (300 females and 262 males) at the age between 11-18 years old showed that the mean of body weight, body height, and the age menarche measured in the year 2005 was higher than the age of menarche measured in 23 years ago. The body height, weight, and age of menarche found were $7.37 \mathrm{~cm}$ (5.1\%), 9.21 $\mathrm{kg}(26.1 \%)$, and 16.6 months (10.6\%) [4].

The younger age of menarche could be related to the social-economic status restoration, nutritional status, and general improvement of health status [5].

A study conducted by Mardisentosa [6] showed that the mean age of menarche on female adolescents in Tangerang, West Java was 12 years old. Similar studies in 1980 also revealed that the mean age of menarche was 13.26 years old. These results indicated that the younger age of menarche affected by various factors, one of them was nutritional status. Nutritional status in each area in Indonesia is relatively varied. A pilot study conducted in Sidorejo Pare Christian Junior High School on November 6th, 2020 revealed that $80 \%$ from 10 female students with good nutritional status had experienced menarche. Their age of menarche was between 10 to 11 years old. Hence, a study related to the correlation between nutritional status and the age of menarche on the female students in Sidorejo Pare Christian Junior High School required to be conducted. Their nutritional status would be measured by the index of body weight/body height according to the Harvard Standard of measurement. 


\section{METHODS}

This was a descriptive correlation study with the survey method and cross-sectional approach. The study population was the thirdyear female students in Sidoarjo Pare Christian Junior High School, with a total of 28 students. The study sample selected by purposive sampling technique. Each participant chosen according to the criteria and characteristics set by study. Twentyeight female students who met the study criteria picked as the study participant. The sample selected based on the inclusion criteria in this study:

Had experienced menarche $\leq 6$ months prior to the study; Willing to participate in the study; Third-year female student; Did not experience any symptoms of diseases for the last two months; While the exclusion criteria were: Not willing to participate in the study; Sick and could not participate in the study. The data in this study collected by two questionnaires, they were:

The first questionnaire employed to select eligible participants in this study. This questionnaire given to the female students and their parents. The question items in this questionnaire developed from the inclusion and exclusion criteria of the study; The second questionnaire employed to collect the study data. The data then analyzed descriptively and analytically in SPSS version 11.0, presented in tables and diagrams. The correlation between nutritional status and the age of menarche was analyzed by Spearman Rank-Test, with the level of significance of $95 \%$ or $\alpha=0.05$. If the statistical analysis shows the value of $\mathrm{p}<0.05, \mathrm{HO}$ is refused, which indicated a correlation between nutritional status and the age of menarche. If the statistical analysis shows $\mathrm{p}>0.05, \mathrm{H} 1$ is refused, which indicated no correlation between nutritional status and the age of menarche. The value of $r$ is required to analyze the strength of the correlation. According to Young (1982) in Wahid Sulaiman, the range of correlation classified into: $0.70-1.00$ (in positive or negative value) show a high degree of association, $0.40-0.70$ (in positive or negative value) show the substantial degree of association, $0.20-0.40$ (in positive or negative value) show a low degree of association, $<0.20$ (in positive or negative value) show the degree of association that could be disregarded in the analysis.

This study had approved by the Research and Community Service Department on behalf of the Director of Insan Cendikia Medika Jombang College of Health Science and the Headmaster of Sidorejo Pare Christian Junior High School. The study data then collected by the researcher. The explanation of the study aim given to the female students before the study. When they agreed to participate, the researcher would ask them to fill and sign the study questionnaires.

The privacy of the participants protected in this study. There was no participant's name use. Instead, a series of codes employed to substitute the participant's name or identity on the study discussion. All information given to the study is protected and private.

\section{RESULTS}

Twenty-five female students who met the inclusion criteria participated in this study. Social demographic characteristics, nutritional status, and the age of menarche 
data were collected to meet the aim of the study. Characteristic of Participant.

The characteristic of participant collected in this study were age, body weight, body height, parent's occupation, and parent's salary. The participant aged between 12 to 15 years old. Fig. 1 shows that the majority of participants $(40 \%)$ were in the age of 14 , while the rest of them were in the age of 12 and 13 . Only $4 \%$ of the participant were in the age of 15 . According to Table 1 and table 2, $80 \%$ of the participant had a mean salary/month of IDR 1,500,000-IDR $2,000,000 /$ month, while $20 \%$ of them had a mean salary of IDR 2,000,000/month. Sixtypercent of the participant's parents were working as civil servants and $40 \%$ of them were working in the private sectors.

Fig. 2 shows that $92 \%$ of the participant had normal nutritional status, only $8 \%$ of them had underweight nutritional status. According to Table 3, the majority of menarche age was 11 years old. While the youngest and oldest percentage of the age of menarche was 9 and 13 years old, respectively. Table 4 shows that $92 \%$ of the participants with normal nutritional status were experiencing menarche at the age of 9 to 11. Eight percent of the participants with underweight nutritional status were experiencing menarche at the age of 12 to 13.

The Correlation Spearman Rho Test showed that the value of $r$ (rho) $=(-0.475)$ with the significance level of $0.016,(p<0.05)$. This result indicated that $\mathrm{H} 0$ refused and $\mathrm{H} 1$ accepted. Hence, there was a correlation between the nutritional status and the age of menarche. The value of Spearman Correlation Test (r) between nutritional status and the age of menarche was $-0,475$. This value revealed that there was a moderate and opposite (negative) characteristic of correlation between the nutritional status and the age of menarche. Better nutritional status resulted in the younger age of menarche.

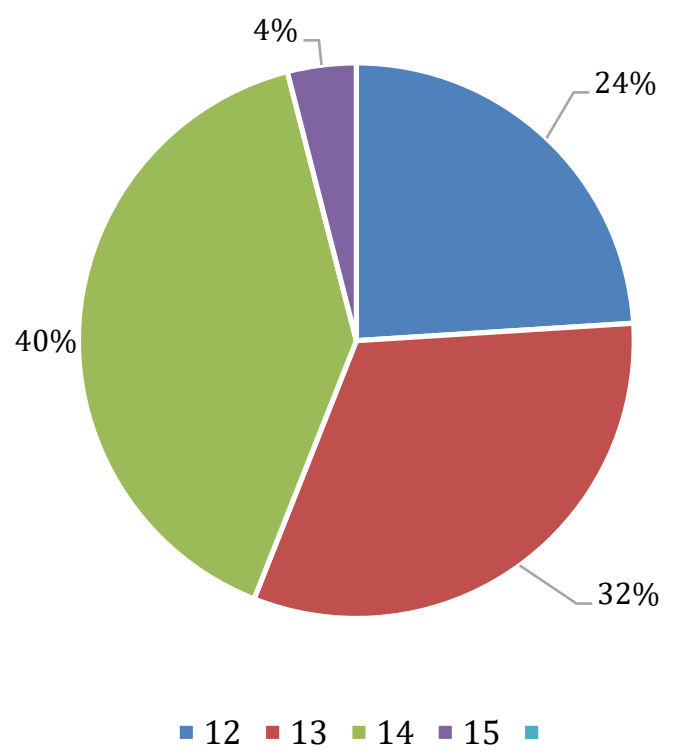

Fig. 1. Participant's Characteristic According to Age 
Table 1

Amount of Monthly Salary of Participant's Parent

\begin{tabular}{cccc}
\hline & Salary per Month & n & \% \\
\hline Between IDR 1,500,000 - IDR 2,000,000 & 20 & 80 \\
$>2,000,000$ & & 5 & 20 \\
\hline \multicolumn{2}{c}{ Total } & $\mathbf{2 5}$ & $\mathbf{1 0 0}$ \\
\hline
\end{tabular}

Table 2

Occupation of Participant's Parent

\begin{tabular}{lccc}
\hline \multicolumn{1}{c}{ Occupation } & n & \% \\
\hline Civil Servant & 7 & 28 \\
Working in Private Sector & 9 & 36 \\
Farmer & Total & 9 & 36 \\
\hline \multicolumn{2}{c}{} & $\mathbf{2 5}$ & $\mathbf{1 0 0}$ \\
\hline
\end{tabular}

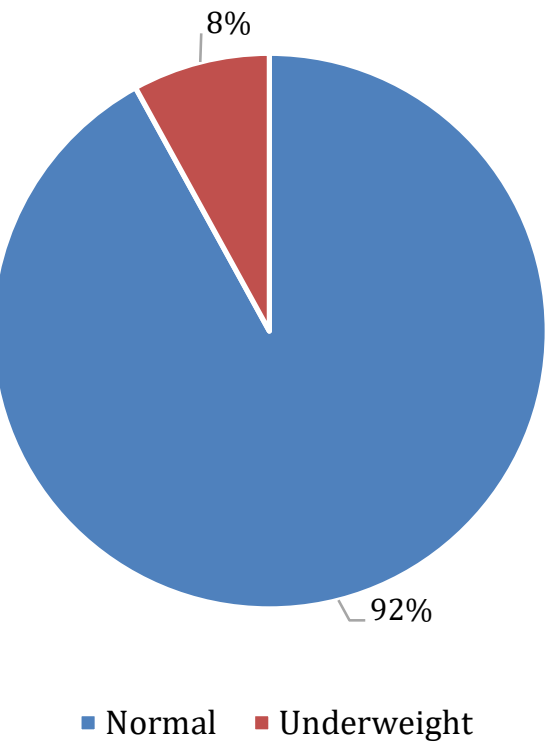

Fig. 2. Nutritional Status Distribution

Table 3

Age of Menarche Distribution

\begin{tabular}{ccc}
\hline Age of Menarche (Year) & $\mathbf{n}$ & $\mathbf{\%}$ \\
\hline 9 & 1 & 4 \\
10 & 2 & 8 \\
11 & 11 & 44 \\
12 & 9 & 36 \\
13 & 2 & 8 \\
\hline Total & $\mathbf{2 5}$ & $\mathbf{1 0 0}$ \\
\hline
\end{tabular}


Table 4

Age of Menarche Distribution According to Nutritional Status

\begin{tabular}{cccc}
\hline \multirow{2}{*}{ Age of Menarche } & \multicolumn{2}{c}{ Nutritional Status } & \multicolumn{2}{c}{$\begin{array}{c}\text { Percentage } \\
\text { (\%) }\end{array}$} \\
\cline { 2 - 4 } & Normal (N) & Underweight (N) & 4 \\
10 & 1 & - & 8 \\
11 & 2 & - & 44 \\
12 & 11 & 1 & 36 \\
13 & 8 & 1 & 4 \\
\hline Total & 1 & $\mathbf{2}$ & $\mathbf{1 0 0}$ \\
\hline
\end{tabular}

\section{DISCUSSION}

Human body required substances in food or nutrition to form, nurture, extracted energy, and regulate the metabolic process. Nutrition in foods such as carbohydrate, protein, fat, mineral, and vitamin play a significant role in the body regulation process run by the nervous and endocrine system.

Body regulation done by the endocrine system would run well if the need for protein and fat could be met adequately. Protein and fat are significant components of hormone formation. Cholesterol in fat is a vital substance for hormone formation. Ovarian employs cholesterol as one substance for progesterone and estrogen formation.

Estrogen stimulated the development of women's reproduction organs, such as the women's genitalia, breast, and secondary sex organs. The changes of ovarian during the sexual cycles completely relied on the secretion of gonadotropic hormones, $\mathrm{FSH}$, and LH secreted by hypophysis anterior glands. Both FSH and LH are glycoproteins. These hormone syntheses and secretion mechanism supported by good nutritional status. Good nutritional status also affected the growth and development of various organs in the body, sexual maturation process and sexual function are one of them that affected by this nutritional status [7].

Table 2 shows that 2 participants (8\%) and 1 participant (4\%) were experiencing menarche at the age of 12 and 13, respectively. In comparison with the rest of the participants, these participants had underweight nutritional status. Consequently, the menarche occurred at an older age. Each female adolescent should have to surpass a certain and different critical bodyweight to experience menarche. It could also depend on their race. A study showed that female adolescents with the age of menarche at 11 had higher body weight in their childhood in comparison to those who experienced menarche at the age of 14. Further, female adolescents with younger age of menarche showed higher BMI and skinfold thickness at their 21 and 27 years of age, in comparison to those who had a younger age of menarche [8].

A study done on a ballet dancer and female gymnastic athlete population who tended to maintain their BMI in normal to underweight nutritional status revealed that there was a reduction in the level of circulating estrogen and several metabolic 
changes in their body. They experienced menarche in older age and also periods of amenorrhea [9]. Participants with normal nutritional status were experiencing menarche in the younger age in comparison with underweight nutritional status. Hence, there was a correlation between the nutritional status and the age of menarche.

Nutritional status affected the sexual maturation process. Therefore it also influences the age of menarche. Generally, early sexual maturity correlated with higher body mass index (BMI) value. At the same age, the female adolescent with a slow sexual maturation process commonly has a lower BMI value. Higher BMI value or interpreted as normal to overweight nutritional status tends to expose with a high concentration of estrogen and progesterone due to the high-fat consumption [10].

\section{CONCLUSION}

According to the result and discussion, we concluded that: The oldest and youngest age of menarche was 11 and 9 years old, respectively. The majority of participants (92\%) in normal nutritional status were experiencing menarche at the age of 9 to 11 . There was a correlation between nutritional status (according to body weight/body height) and the age of menarche with a pvalue of 0.016 and $r=-0.475$. A better nutritional status resulted in a younger age of menarche.

We suggested to do more intensive health education-related to nutrition and reproductive health to the female students. This type of education could be managed by teachers in order to prevent the case of anemia on female students, especially for those students who had already experienced menstruation.

\section{REFERENCES}

[1] Marmi, Gizi dalam Kesehatan Reproduksi. Yogyakarta: Pustaka Pelajar, 2013.

[2] E. C. Jansen, "Early-life determinants of the age at menarche by Erica Christine Jansen A dissertation submitted in partial fulfillment of the requirements for the degree of Doctor of Philosophy (Epidemiological Science) in the University of Michigan Doctoral Committe," 2016.

[3] A. S. Proverawati, Buku Ajar Gizi untuk Kebidanan. Yogyakarta: Nuha Medika, 2009.

[4] N. T. Rahmawati and J. Hastuti, "Secular Changes In Body Size And Menarche age of Javanese Adolescent in Yogyakarta," Berkala Ilmu Kedokteran, vol. 37, no. 4, pp. 171-176, 2005.

[5] A. Bagga and S. Kulkarni, "Age at menarche and secular trend in Maharashtrian (Indian) girls," Acta Biol. Szeged., vol. 44, no. 1-4, pp. 53-57, 2000.

[6] B. Mardisentosa, S. Nurhasanah, A. Pratiwi, D. N. Puspita Sari, and I. Sartika, "Status Gizi Terhadap Usia Menarche Pada Seluruh Siswi Di Smp Negeri 5 Pasar Kemis Kabupaten Tangerang," Edu Dharma J. J. Penelit. dan Pengabdi. Masy., vol. 4, no. 2, p. 122, 2020, doi: 10.52031/edj.v4i2.65.

[7] H. J. E. Guyton A. C., Buku Ajar Fisiologi Kedokteran. Edisi 9. Jakarta: EGC, 1997. 
[8] Sudikno, H. Syarief, C. Meti Dwiriani, and H. Riyadi, “Faktor Risiko Obesitas Sentral Pada Orang Dewasa Umur 25-65 Tahun Di Indonesia (Analisis Data Riset Kesehatan Dasar 2013) (Risk Factors Central Obesity in 25-65 Year-Old Indonesian Adults [Analysis Data of Basic Health Research 2013])," Penelit. Gizi dan Makanan, vol. 38, no. 2, pp. 111120, 2015.

[9] P. A. Rachmawati and E. A. Murbawani, "Hubungan Asupan Zat Gizi, Aktivitas
Fisik, Dan Persentase Lemak Tubuh Dengan Gangguan Siklus Menstruasi Pada Penari," J. Nutr. Coll., vol. 4, no. 1, pp. 39-49, 2015, doi: 10.14710/jnc.v4i1.8619.

[10] K. A. Derina, Faktor-Faktor yang Berhubungan dengan Usia Menarche pada Remaja Putri di SMP N 155, Skripsi. Jakarta: Universitas Islam Negeri Syarif Hidayatullah, 2011. 